\title{
ISLAMIC FUNDAMENTALISM IN MODERN RUSSIA
}

\author{
Elena F. Parubochaya \\ Volgograd State University, Volgograd, Russian Federation
}

\begin{abstract}
Nowadays Islam takes the stage of recovery associated with the peculiar issues associated with the Muslim society. These characteristics are expressed in the spread of ideas of Islamic fundamentalism and its supporters' confrontation with the rest of the world. This process has affected the Russian Muslims as well, the trend developed after the collapse of the Soviet Union when the post soviet muslims began to realize themselves as part of one of the Muslim Ummah, coming into conflict with the secular law of the Russian Federation. After the Soviet Union's disintegration, the radical Islamic ideas have begun to appear in Russia, in the conditions of the growth of nationalism these thoughts found a fertile ground. One of these ideas was associated with the construction of Sharia state in the Muslim autonomous republics of the Russian Federation and their subsequent withdrawal from Russian's membership.

The situation for the Russian state in the Muslim republics aggravated the war in Chechnya. Through Chechnya mercenaries from Arab countries started to penetrate to the Russian territory, they also brought the money for the destabilization of the internal situation in Russia. Nevertheless, separatism did not find the mass support in neighboring regions such as Dagestan, Kabardino-Balkaria, Karachay-Cherkessia and Ingushetia. It is evidently that international Jihad ideas were supported financially from abroad. The issue of funding is a key part of the development of Islamic fundamentalism in Russia, the international Islamic funds and organizations gave huge financial assistance to them. At the present moment Russian authorities lead a fruitful and a successful fight against terrorism. In the future, after the completion of the antiterrorist operation in the Middle East hundreds of terrorists may return to Russia with huge experience that can threaten the security of the Russian state.
\end{abstract}

Key words: revival of Islam, Islamic fundamentalism, measures to counter terrorism, religious communities of Muslims, Wahhabi organization.

Citation. Parubochaya E.F. Islamic Fundamentalism in Modern Russia. Vestnik Volgogradskogo gosudarstvennogo universiteta. Serija 4, Istorija. Regionovedenie. Mezhdunarodnye otnoshenija [Science Journal of Volgograd State University. History. Area Studies. International Relations], 2017, vol. 22, no. 3, pp. 150-160. (in Russian). DOI: https://doi.org/10.15688/jvolsu4.2017.3.14.

\section{ИСЛАМСКИЙ ФУНДАМЕНТАЛИЗМ В СОВРЕМЕННОЙ РОССИИ}

\section{Елена Федоровна Парубочая}

Волгоградский государственный университет, г. Волгоград, Российская Федерация

Аннотация. В настоящее время исламская религия проходит стадию подъема, связанного с особенностями мусульманского общества. Эта тенденция выражается в распространении идей исламского фундаментализма и активном противоборстве его сторонников со всем остальным миром. Данный процесс затро-

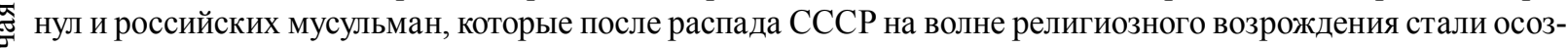
навать свою религиозную идентичность и принадлежность к мировой мусульманской умме, что приводит к противоречию со светским законом РФ.

Ключевые слова: возрождение ислама, исламский фундаментализм, меры по противодействию терроризма, религиозные объединения верующих мусульман, организация ваххабитского толка. 
Цитирование. Парубочая Е. Ф. Исламский фундаментализм в современной России // Вестник Волгоградского государственного университета. Серия 4, История. Регионоведение. Международные отношения. 2017. - T. 22, № 3. - C. 150-160. - DOI: https://doi.org/10.15688/jvolsu4.2017.3.14.

Приступая к исследованию такого понятия, как исламский фундаментализм, первоначально следует внести ясность в категориальный аппарат. Рассуждая на тему фундаментализма, директор НИИ гуманитарных наук Чеченской Республики Вахид Акаев, пишет, что данный термин не имеет исламского происхождения, а появился на Западе и, будучи «искусственно экстраполированным на ислам, сегодня он стал предметом широких общественных и научных дискуссий, отразившихся в многочисленных публикациях как на Западе, так и в России. В исламе же фундаментализм выражается термином “усул ад-дин”, означающим “корни”, “основы”, “фундамент”. Вместе с тем более употребимым термином, которым именуют себя исламские фундаменталисты, является “салафизм"» [1]. Исследователь А. Игнатенко и некоторые другие авторы полагают, что этот термин произошел «от выражения “ассалаф ас-салих" (“праведные предки”) или “просто ас-салаф” (“предки”). Сторонники салафизма выступают за то, чтобы мусульмане во всех своих действиях и верованиях, нормах и правилах следовали тому, что существовало и делалось в период первоначального ислама». При этом салафизм (стремящийся вернуться к истокам, невзирая на уже совершенное движение во времени) явление противоположное по отношению к традиционализму, который несет историческую нагрузку, вбирает в себя наиболее ценные национальные особенности, приводя их в соответствие с «догмами веры» [21].

Возрождение же ислама на современном этапе зачастую связывают с понятием исламский фундаментализм, что рассматривается как возврат к религиозному, социальному и политическому опыту раннего ислама времен пророка Мухаммеда [23, с. 425]. Это означает неукоснительное выполнение предписаний Корана и шариата, введение традиционных мусульманских установлений в качестве обязательных норм современной жизни [18]. Начало развития исламского фундаментализма на современном Ближнем Востоке связыва- ют с деятельностью организации «Братьямусульмане» ${ }^{1}$, созданной Хасаном аль Банной в Каире в 1928 г. [27, с. 224].

В дальнейшем идеи фундаментализма развивал и радикализировал другой представитель этой организации Сайид Кутб [23, c. 426]. Важными вехами в становлении фундаментализма стали арабо-израильская война 1967 г. и Исламская революция 1979 г. в Иране, ускорившая процесс радикализации идей среди шиитского меньшинства в неарабских государствах. Распространению фундаментализма способствовали и военные операции, проводимые США и их союзниками в отношении Ирака и Афганистана, которые способствовали сплочению фундаменталистов в борьбе с общим врагом и сильно радикализовали их движения, что привело к появлению ИГИЛ [20]. Процессы, проходящие в исламском мире, затронули и российских мусульман, составляющих около $10 \%$ населения России на момент последней Всероссийской переписи населения [3].

Согласно последним оценкам, число мусульманского населения РФ на конец 2016 г. составило 15 \% [26]. Осознание мусульманами СССР себя частью единой мусульманской уммы тормозилось активностью советской пропаганды атеизма, поэтому сторонники традиционного ислама на Северном Кавказе суфизма, а в Татарстане приверженцы мазхаба имама Абу Ханифы за 70 лет советской власти довольно сильно ослабили свои позиции. Однако этот вакуум стал быстро заполняться после распада Союза.

Необходимо выявить механизмы влияния различных исламских течений, наносящих угрозу РФ, и возможности их воздествия на российскую внутриполитическую ситуацию. На территорию РФ начали проникать различные исламские идеи, которые в условиях роста национализма нашли для себя благодатную почву. Одна из таких идей была связана с построением шариатских государств в мусульманских автономных республиках России с последующим их выходом из ее состава [24, с. 204]. Активными распространителями этой 
шариатской доктрины для Северного Кавказа были Багаутдин Магомедов и Аббас Кебедов. Пропагандируемые ими идеи ваххабизма получили в 90-е гг. прошлого века поддержку части населения автономных республик Северного Кавказа, Поволжья и Предуралья. Этому способствовало то, что многие новоиспеченные мусульмане в большинстве своем были безграмотны в вопросах вероучения ислама и не могли вскрыть противоречивость идей «неосалафитов», «джихадистов» и «ваххабитов», которые являлись защитниками исламского фундаментализма. Мусульмане зачастую не понимали, что с точки зрения традиционного ислама ваххабиты находились в глубоком заблуждении, вынося такфир (обвинение в неверии) не поддерживающим их мусульманам [37].

Ситуацию для российской государственности в мусульманских республиках усугубили боевые действия в Чечне. Через Чечню в Россию стали проникать наемники из арабских стран, а с ними и деньги для организации дестабилизации ситуации в России [28, с. 145]. Активное участие в боевых действиях в Чечне приняли сторонники, разделявшие идеи мирового джихадизма из «Аль-Каиды» и «Талибана». Данные террористические организации не ограничивались только засылкой боевиков в Россию, они пересылали в Чечню оружие и деньги [4].

Помимо материальной поддержки, «АльКаида» занималась и духовно-просветительской деятельностью в духе салафизма, то есть ваххабизма. Своими доводами члены «АльКаиды» и других террористических организаций смогли склонить многих чеченцев-суфиев к ваххабизму, таким образом, еще более радикализовав их [2]. Чеченская война достаточно быстро переходила из националистической фазы в религиозную. В этой войне сторонники Д. Дудаева ощущали солидарность почти всего мусульманского мира, правда, только на неофициальном уровне. Официально Чеченскую Республику Ичкерия (далее ЧРИ) не признало ни одно государство - член $\mathrm{OOH}[33]$.

Стоит отметить, что очень жесткую позицию продемонстрировали духовные лица исламского мира на Ближнем Востоке, которые официально выступили против России и призвали к джихаду против нее. Верховный муфтий Саудовской Аравии Абдуль Азиз ибн Баз еще в апреле 1995 г. издал фетву «Об обращении к мусульманам для помощи Чечне». В фетве он говорил, что «нужно протянуть руку... братьям в Чечне и послать им помощь: муджахидами, оружием и деньгами - против поганых коммунистов» [38].

Есть основания считать, что фетва была издана под влиянием короля Фахда, заинтересованного в политическом влиянии на Кавказ, обходя официальный формат отношений, на котором признание ЧРИ было невозможно. Другой салафитский ученый Хамуд ибн Укла аш-Шуайби, находившийся в оппозиции Саудовскому правительству и известный своей непримиримостью к иноверцам и любовью к муджахидам, 23 мая 1999 г. издал фетву «Указание джихада в Чечне и обязанность мусульман участвовать в нем». В фетве он обращал внимание на то, что «борьба вместе с... братьями в Чечне - это долг и обязанность каждого мусульманина» [39]. Таким образом, именно Чечня стала объектом их пристального внимания. Формы и размеры оказанной ей помощи будут рассмотрены ниже.

Что касается других республик Кавказа, то, в отличие от Чечни, массовой поддержки в соседних регионах, таких как Дагестан, Кабардино-Балкария, Карачаево-Черкесия и Ингушетия, идеи исламского фундаментализма не нашли. Этому способствовало принятие в этих республиках законов, запрещающих деятельность экстремистских, в том числе и ваххабитских организаций. Самой первой северокавказской республикой, запретившей ваххабизм на официальном уровне, стала Ингушетия. В августе 1996 г. правительство республики приняло закон «О свободе вероисповедания и религиозных организациях». Закон декларировал право «высказывать и распространять религиозные взгляды и убеждения в устной и любой другой форме при условии, если эта деятельность не противоречит настоящему Закону и не сопровождается нарушением общественного порядка и посягательствами на личность и права граждан» [11].

Изложенная статья иносказательно утверждала, что идеи ваххабизма, в силу их очевидного противоречия закону РФ, считаются запрещенными. Принятие ингушским 
правительством данного законопроекта было следствием того, что чеченский и ингушский народы объединены одной вайнахской культурой. Исходя из этого сепаратистские устремления в Чечне могут перекинуться на Ингушетию гораздо быстрее, чем на другие республики Северного Кавказа.

В других республиках этот закон принимался гораздо дольше вследствие того, что угроза распространения ваххабизма и сепаратизма не стояла так остро, как в Ингушетии. Но после вторжения боевиков в Дагестан ситуация резко изменилась, и сентябре 1999 г. в Республике Дагестан был принят закон «О запрете ваххабитской и иной экстремистской деятельности на территории Республики Дагестан». В законе прописывался запрет на создание и функционирование ваххабитских объединений; также запрещалась деятельность религиозных миссий, учебных заведений, благотворительных фондов, носящих экстремистские идеи; обучение граждан за границей стало осуществляться исключительно по направлению муфтията республики Дагестан [10]. Аналогичный закон «О противостоянии политическому и религиозному экстремизму на территории Карачаево-Черкесской Республики» (далее - КЧР) был принят 4 мая 2000 г. постановлением президиума Народного собрания КЧР. Основное положение закона гласило: «запрещается создание и деятельность общественных, политических и религиозных объединений, носящих экстремистский характер» [9]. Чеченская республика приняла такой закон в 2000 г., но эффективность его действия была незначительной, так как в это время шла вторая чеченская кампания. В финансировании ваххабитов в Чечне и других Северокавказских республиках в начале 2000-х начались проблемы, связанные с тем, что после 11 сентября 2001 г. США ужесточили контроль над перемещением валютных средств, а также активной политикой В.В. Путина, поставившего цель урегулировать чеченский вопрос [20].

Другим фактором затухания активного противостояния ваххабитов федеральным властям является то, что многие иностранные муджахиды вошли в конфликт с населением Чечни, которое не хотело принимать «чистый Ислам» и отказываться от суфизма. Покро- вители мирового джихада стали уезжать в другие горячие точки, прежде всего в Ираке [7]. Ввиду военного поражения в Чечне и перехода на нелегальное положение в других республиках Северного Кавказа, экстремистские элементы стали менять свои методы работы с верующими. Ставка была сделана на молодежь. Юноши из мусульманских регионов России получали приглашения для обучения на богословских факультетах университетов стран Персидского залива и Саудовской Аравии, в которых официальной идеологией на данный момент является ваххабизм в его классической форме [25].

Выезд молодежи за рубеж осуществлялся как официально, так и неофициально в такие вузы, как Аль-Азхар в Египте, Исламский университет Мекки, Мединский Исламский университет, Университет имама Сауда в Эр-Рияде, Международный Исламский университет Исламабада. Тех, кто отправлялся на учебу по направлению муфтията, духовные управления обеспечивали социальными пакетами, стипендией и жильем. Те лица, которые выезжали самостоятельно, без финансовой поддержки, из-за финансовых затруднений на чужбине зачастую попадали под влияние радикальных элементов. Исследователи Ислама указывали, что в 1990-е гг. более 4 тыс. мусульман получали исламское образование за рубежом. По данным на 2009 г., около 3 тыс. студентов получали образование за рубежом, из них только 200 человек - по направлению муфтията [8]. Естественно, многие бакалавры этих исламских университетов возвращались в Россию уже убежденными салафитами и, становясь имамами, активно пропагандировали джихадизм, делали акцент на эту сторону исламской религии в хутбах. Примером тому могут служить такие известные проповедники салафитской доктрины, как Саид Бурятский, Абу Умар Саситлинский, Надыр абу Халид, окончившие зарубежные исламские университеты и читавшие лекции в мечетях Северного Кавказа и континентальной России.

Совершенно очевидно, что сторонники международного джихада не имели бы в России поддержки, если бы не получали из-за рубежа финансовой помощи. Вопрос финансирования является ключевым в рамках раз- 
вития исламского фундаментализма в России, так как люди, проповедующие эту идею самостоятельно, зачастую ограничены в финансовых возможностях и стоят вне закона. Для их поддержки международные исламские фонды и организации выделяют колоссальные суммы.

Среди этих фондов можно выделить такую организацию, как Международная исламская организация «Спасение» (далее-МИОС). Ее целью является оказание помощи мусульманам - жертвам войны, религиозных конфликтов, стихийных бедствий, антиисламских религиозных преследований. С началом чеченской войны МИОС запустила программу «Король Фахд - Чеченскому народу», по которой оказывалась помощь беженцам. Официально программа не носила антироссийской направленности и не ставила своей целью спонсирование Д. Дудаева, но на неофициальном уровне исключить такое невозможно. В 1998 г. программа была переименована в «Объединенный Саудовский комитет спасения Косово и Чечни». Образованный комитет получил право на сбор пожертвований для Чечни и к концу 1990-х гг. была собрана колоссальная сумма в размере 125 млн саудовских риалов. В одних только мечетях прихожане собрали 1 млн 122 тыс. риалов [17].

Вообще тема Чечни очень болезненна для саудовского общества. Население Королевства Саудовская Аравия (далее - КСА) поддерживало своих борющихся братьев по исламу, о чем свидетельствуют вышеописанные фетвы ученых и даже современные сайты, посвященные Чечне. Заголовки статей сайта называются «Чечня - забытая земля Джихада», «Чечня боль и слезы Ислама», на этих сайтах очень популярна идея джихада в Чечне, борьба чеченцев за свою свободу против России, необходимая помощь братьям по вере [40]. Для поддержки ваххабитской идеологии в России и сепаратистских устремлений фонд «Аль-Харамейн» в 2005 г. переправил в Чечню 150 тыс. долл. на поддержку борьбы за независимость Ичкерии [13]. Катарский благотворительный фонд «Катар» передал боевикам Дагестана в 1999 г. 500 тыс. долларов. Иорданское отделение «Братьев-мусульман» в начале 1999 г. передало Чечне около 20 млн долл. [16]. Такие колоссальные вливания не могли пройти неза- метно: вследствие постоянной финансовой подпитки ваххабизм имеет возможность и каналы для усиления влияния в России. Проявления этого процесса многообразны:

1. Появляются религиозные объединения верующих мусульман, которые ограничивают контакты с обществом. Примером таких объединений являются ваххабитские джамааты. Одним из таких объединений является Аюбовский джамаат, который находился в Астрахани с начала 1990-х годов. Лидером данной организации считался Ангута Омарович Ангутаев, или Аюб Астраханский. Организация исповедовала «чистый Ислам», освобожденный от многих наслоений, опираясь на опыт Саудовской Аравии [19]. Другая ваххабитская организация носила название джамаат «Ярмук». Она находилась в КабардиноБалкарии, ее лидерами считались Муса Мукожев и Анзор Астемиров. Организация занималась подрывной деятельностью на Северном Кавказе и была замечена в связях с Басаевым и Хаттабом [6]. Еще одна организация ваххабитского толка существовала в Карачаево-Черкесии и носила название «Карачаевский джамаат». Ее лидерами были Рамазан Борлаков и Ачемез Гочияев. Джамаат занимался подрывной деятельностью в России и на Северном Кавказе. Им были организованы серии терактов в Москве, Волгодонске, Ставропольском крае. Члены организации принимали активное участие во второй чеченской кампании [14].

2. Активизировалась деятельность мусульманских объединений, на базе которых осуществляется теологическое образование и воспитание детей и подростков в духе законов шариата. Так, на 1 января 2005 г. зарегистрированы 3634 общины [34]. На 1 января 2011 г. была зарегистрирована 4201 община [35]. На 1 января 2015 г. их число возросло до 4998 общин [36]. Данные статистики явно демонстрируют рост числа мусульманских объединений.

3. Мусульманскими лидерами пропагандируется необходимость совершения культовых действий. Исполнение обряда хаджа, являющегося одним из столпов ислама, согласно данным статистики в 2003 г., совершили 4300 человек, 2005 г. - 9100 человек, 2008 26500 человек [12]. Указанные цифры под- 
тверждают рост интереса к религии у населения, исповедующего ислам в РФ.

4. Появились и действуют исламские банки. Примером являются банки «Амаль» и «Бадр» [15].

5. Среди некоторых верующих нелегально осуществляется сбор средств для ИГИЛ. Эта деятельность организовывалась через различные сайты. Более 450 таких сайтов были заблокированы Генпрокураторой РФ, проводится постоянная работа по их выявлению и блокированию [5].

6. Добровольцы из российских мусульман воюют в рядах ИГИЛ [22] и т.д.

Распространение фундаментализма в современной России стало возможным, как нам представляется, благодаря пассивной политике руководства страны в первой половине 1990-х гг., когда появился фундамент для проникновения в РФ ваххабитской доктрины. Важность борьбы с этой идеей руководство России начало осознавать только после первой чеченской кампании, где ваххабизм проявил себя в высшей степени сепаратизма. После фактического окончания боевых действий в Чечне. В Северокавказских республиках начали принимать законы о противодействии ваххабитской и иной экстремисткой деятельности, что было описано выше. С приходом к власти В.В. Путина, укреплением центральной власти в РФ, принятием мер по противодействию ваххабизму, так же как и экстремисткой деятельности на территории РФ, стало уделяться особое внимание.

Успешной борьбе способствовало расширение законодательной базы по противодействию экстремизма и терроризма. Так, в июле 2002 г. был принят закон «О противодействии экстремистской деятельности». Статья 7 Ф3 гласила: «Если в течение двенадцати месяцев со дня вынесения предупреждения выявлены новые факты, свидетельствующие о наличии признаков экстремизма в их деятельности, в установленном настоящим Федеральным законом порядке соответствующие общественное или религиозное объединение, либо иная организация подлежит ликвидации, а деятельность общественного или религиозного объединения, не являющегося юридическим лицом, подлежит запрету» [30]. Исходя из положения закона, ваххабитские организа- ции, деятельность которых явно противоречит российскому закону, подлежали запрету на всей территории России.

15 февраля 2006 г. указом президента РФ «О мерах по противодействию терроризму» был образован национальный антитеррористический комитет, в задачу которого входила борьба со всеми проявлениями терроризма на территории РФ [29]. 6 марта 2006 г. был принят новый Ф3 № 35 «О противодействии терроризму». Предусматривалось создание организации, основной функцией которой является предупреждение и пресечение террористической деятельности на территории РФ. Основные полномочия по борьбе с терроризмом возлагаются на ФСБ [31]. Стоит отметить, что в июле 2016 г. были приняты два законопроекта, носящие антитеррористическую направленность, под общим названием «Пакет Яровой». Данные законопроекты ужесточали уголовное наказание за террористическую деятельность, разрешили следователям получать информацию из электронной переписки, что нарушает естественное право человека на неприкосновенность его личной жизни [32].

На данный момент по сравнению с 1990-ми гг. и началом 2000-х гг. в РФ идет плодотворная и успешная борьба с терроризмом. В качестве механизмов влияния и распространения исламского фундаментализма используются различные благотворительные фонды, оказывающие финансовую поддержку, используются образовательные рычаги, среди которых обучение в исламских университетах Саудовской Аравии, Египта. При условии все большего приобщения исламского населения к религии, росту популярности ислама, хаджа и обрядовых мероприятий весьма очевидна возможность активизации проникновения исламского фундаментализма при условии ослабления центральной власти в РФ. В перспективе после завершения антитеррористической операции сотни террористов могут вернуться в Россию с боевым опытом, что может угрожать безопасности российского государства.

\section{ПРИМЕЧАНИЕ}

1 «Братья-мусульмане», ИГИЛ, «Аль-Каида», «Талибан» - запрещенные в России организации. 


\section{СПИСОК ЛИТЕРАТУРЫ}

1. Акаев, В. Исламский фундаментализм на Северном Кавказе: миф и реальность / В. Акаев // Центральная Азия и Кавказ. - Электрон. текстовые дан. - Режим доступа: http://www.ca-c.org/ journal/cac-09-2000/15.Akaev.shtml (дата обращения: 12.10.2016). - Загл. с экрана.

2. Борисов, А. В. Война в Чечне и Исламский мир / А. В. Борисов // Ближний Восток и современность. - 2001.- Вып. 11. - С. 61-69.

3. Всероссийская перепись населения за 2010 год// Росстат. - Электрон. текстовые дан. - Режим доступа: http://www.gks.ru/free doc/new site/ perepis2010/croc/perepis_itogi1612.htm (дата обращения: 10.10.2016). - Загл. с экрана.

4. В Чечне воюют иностранные наемники и турецкие спецслужбы (письма боевиков) // Центр Азия.ру. - Электрон. текстовые дан. - Режим доступа: http://www.centrasia.ru/newsA.php?st= 1099730700 (дата обращения: 27.09.2016). - Загл. с экрана.

5. Генпрокуратура отчиталась о блокировке 450 сайтов для сбора помощи ИГИЛ // Слон. ру. Электрон. текстовые дан. - Режим доступа: https:// slon.ru/posts/59437 (дата обращения: 30.09.2016). Загл. с экрана.

6. Джамаат Ярмук // Вести.ру. - Электрон. текстовые дан. - Режим доступа: http://www.vesti.ru/ doc.html?id=117504 (дата обращения: 30.09.2016). Загл. с экрана.

7. Дзуцев, Х. В. Ваххабиты на Северном Кавказе - религия, политика, социальная практика / Х. В. Дзуцев, А. И. Першиц // Вестник Российской Академии наук. - 1998. - Т. 68, № 12. - С. 1113-1116.

8. Добаев, И. Мусульманское образование в России: состояние, проблемы и перспективы на Северном Кавказе / И. Добаев // Перспективы. Инфо. Электрон. текстовые дан. - Режим доступа: http:// www.perspektivy.info/book/musulmanskoje obrazovanije_v_rossii_sostojanije_problemy_i_ perspektivy_na_severnom_kavkaze_2008-06-04.htm (дата обращения: 30.09.2016). - Загл. с экрана.

9. Закон Карачаево-Черкесской Республики от 4.05.2000 № 6-P3 «О противодействии политическому и религиозному экстремизму на территории Карачаево-Черкесской республики» // Электронный фонд правовой и нормативно-технической документации. - Электрон. текстовые дан. - Режим доступа: http://docs.cntd.ru/document/459904482 (дата обращения: 10.10.2016). - Загл. с экрана.

10. Закон Республики Дагестан от 22.09.1999 № 15 «О запрете ваххабитской и иной экстремистской деятельности на территории республики Дагестан» // Электронный фонд правовой и нормативнотехнической документации. - Электрон. текстовые дан. - Режим доступа: http://base.garant.ru/26502658/ (дата обращения: 10.10.2016). - Загл. с экрана.

11. Закон Республики Ингушетия от 23.08.1996 № 13-Р3 «О свободе вероисповеданий и религиозных организациях» // Электронный фонд правовой и нормативно-технической документации. - Электрон. текстовые дан. - Режим доступа: http:// docs.cntd.ru/document/459800341 (дата обращения: 10.10.2016). - Загл. с экрана.

12. История Хаджа Российского // Ислам.ру. Электрон. текстовые дан. - Режим доступа: http:// www.islam.ru/content/history/30993 (дата обращения: 30.09.2016). - Загл. с экрана.

13. Калинина, А. Басаев приберет к рукам кубышку террористов / А. Калинина // Утро.ру. Электрон. текстовые дан. - Режим доступа: http:// www.utro.ru/articles/2005/03/09/415315.shtml (дата обращения: 30.09.2016). - Загл. с экрана.

14. Карачаево-Черкесский джамаат // Агентуpa.py. - Электрон. текстовые дан. - Режим доступа: http://studies.agentura.ru/to/russia/kchr/ (дата обращения: 30.09.2016). - Загл. с экрана.

15. Князев, В. В России стартует исламский банкинг / В. В. Князев // Руэкономикс.ру. - Электрон. текстовые дан. - Режим доступа: http://rueconomics.ru/ 166195-v-rossii-startuet-islamskii-banking (дата обращения: 30.09.2016). - Загл. с экрана.

16. Малашенко, А. В. Исламское возрождение в современной России / А. В. Малашенко // Кавказузел.еу. - Электрон. текстовые дан. - Режим доступа: http://www.kavkaz-uzel.eu/articles/11411/ (дата обращения: 30.09.2016). - Загл. с экрана.

17. Международная исламская организация «Спасение» // Политиктайм.ру. - Электрон. текстовые дан. - Режим доступа: http://www.politictime.ru/ potis-404-1.html (дата обращения: 30.09.2016). - Загл. с экрана.

18. Мусульманский фундаментализм // Исламская энциклопедия. - Электрон. текстовые дан. Режим доступа: http://islamist.ru (дата обращения: 30.10.2016). - Загл. с экрана.

19. Неуловимый Аюб // Время новостей.ру. Электрон. текстовые дан. - Режим доступа: http:// www.vremya.ru/2003/1/13/30836.html (дата обращения: 30.09.2016). - Загл. с экрана.

20. Нечитайло, Д. А. Джихадисты с Северного Кавказа в Сирии: между «Джабхат ан-нусра» и «Исламским государством Ирака и Леванта» / Д. А. Нечитайло // Институт Ближнего Востока. - Электpoн. текстовые дан. - Режим доступа: http:// www.iimes.ru/?p=20237 (дата обращения: 27.09.2016). - Загл. с экрана.

21. Пролетенкова, С. Е. Исламский фундаментализм: сущность, тенденции, особенности / С. Е. Пролетенкова // Of-law.ru. - Электрон. текстовые дан. Режим доступа: http://of-law.ru/stati/islamskij- 
fundamentalizm-sushchnost-tendentsii-osobennosti. html (дата обращения: 27.03.2017). - Загл. с экрана.

22. 5000 россиян воюют в рядах ИГИЛ: комментарии экспертов // Русвесна.су. - Электрон. текстовые дан. - Режим доступа: http://rusvesna.su/ news/1434706866 (дата обращения: 30.09.2016). Загл. с экрана.

23. Религиоведение // Энциклопедический словарь. - М. : Академический проект, 2006. - 1256 с.

24. Садиков, М. И. Религиозно-политический экстремизм / М. И. Садиков, К. М. Ханбабаев. Махачкала : ИТИМО, 2009. - 432 с.

25. Силантьев, Р. А. Ваххабитский проект для Северного Кавказа / Р. А. Силантьев // Независимая газета.ру. - Электрон. текстовые дан. - Режим доступа: http://www.ng.ru/ng_religii/2010-01-20/4_kavkaz.html (дата обращения: 27.09.2016). -Загл. с экрана.

26. Сколько мусульман живет в разных странах мира? // Muslim.ru. - Электрон. текстовые дан. Режим доступа: www.islam-portal.ru (дата обращения: 27.09.2016). - Загл. с экрана.

27. Торкунов, А. В. Современные международные отношения / А. В. Торкунов. - М. : РОССПЭН, 1999. $-584 \mathrm{c}$.

28. Трошев, Г. Н. Моя война. Чеченский дневник окопного генерала / Г. Н. Трошев. - М. : Вагриyc, $2001 .-211 \mathrm{c}$.

29. Указ Президента РФ от 15.02.2006 № 116 «О мерах по противодействию терроризму» : (с изм. и доп.). - Доступ из справ.-правовой системы «КонсультантПлюс».

30. Федеральный закон от 25.07.2002 № 114-Ф3 «О противодействии экстремистской деятельности» : (с изм. и доп.). - Доступ из справ.-правовой системы «КонсультантПлюс».

31. Федеральный закон от 06.03.2006 № 35-Ф3 «О противодействии терроризму». - Доступ из справ.-правовой системы «КонсультантПлюс».

32. Федеральный закон от 06.07.2016 № 375-Ф3 «О внесении изменений в Уголовный кодекс Российской Федерации и Уголовно-процессуальный кодекс Российской Федерации в части установления дополнительных мер противодействия терроризму и обеспечения общественной безопасности». - Доступ из справ.-правовой системы «КонсультантПлюс».

33. Чеченская Республика Ичкерия // Кавказский узел. - Электрон. текстовые дан. - Режим доступа: http:/www.kavkaz-uzel.eu/articles/146418/ \#note 1. - Загл. с экрана.

34. Число религиозных организаций, зарегистрированных в Российской Федерации на 1 января 2005 года // Федеральная служба государственной статистики. - Электрон. текстовые дан. - Режим доступа: http://www.gks.ru/bgd/regl/brus05/IssWWW. exe/Stg/02-07.htm (дата обращения: 10.10.2016). - Загл. с экрана.
35. Число религиозных организаций, зарегистрированных в Российской Федерации на 1 января 2011 года // Федеральная служба государственной статистики. - Электрон. текстовые дан. - Режим доступа: http://www.gks.ru/bgd/regl/b11_13/ IssWWW.exe/Stg/d1/02-13.htm (дата обращения: 10.10.2016). - Загл. с экрана.

36. Число религиозных организаций, зарегистрированных в Российской Федерации на 1 января 2015 года // Федеральная служба государственной статистики. - Электрон. текстовые дан. - Режим доступа: http://www.gks.ru/free_doc/doc_2015/rusfig/ rus-15.pdf(дата обращения: 10.10.2016). - Загл. с экрана.

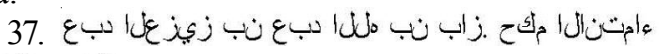
ثيفوصلا قرطلا على (Абдуль-Азиз ибн Баз. Положение присоединения к суфийским тарикатам). Электрон. текстовые дан. - Режим доступа: http:// www.binbaz.org.sa/noor/1159 (дата обращения: 10.10.2016). - Загл. с экрана.

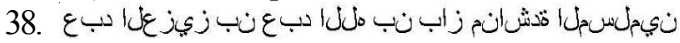

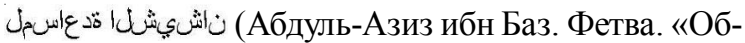
ращение к мусульманам для помощи Чечне»). Электрон. текстовые дан. - Режим доступа: http:// www.binbaz.org.sa/article/430 (дата обращения: 10.10.2016). - Загл. с экрана.

39. ناشيشان (Шейх Хамуд бин Укла аш-Шуайби. Фетва. «Указание Джихада в Чечне и обязанность мусульман участвовать в нем»). - Электрон. текстовые дан. - Режим доступа: https:/saaid.net/ Warathah/hmood/h48.htm (дата обращения: 10.10.2016). - Загл. с экрана.

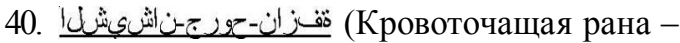
Чечня). - Электрон. текстовые дан. - Режим доступа: http://islamstory.com/ar/ (дата обращения: 10.10.2016). - Загл. с экрана.

\section{REFERENCES}

1. Akaev V. Islamskiy fundamentalizm na Severnom Kavkaze: mifi realnost. Tsentralnaya Aziya $i$ Kavkaz [Islam fundamentalism on North Caucasus: myth and reality]. URL: http://www.ca-c.org/journal/ cac-09-2000/15.Akaev.shtml (accessed October 12, 2016).

2. Borisov A.V. Voyna v Chechne i Islamskiy mir [The War in Chechnya and the Islamic World]. Blizhniy Vostok $i$ sovremennost, 2001, iss. 11, pp. 61-69.

3. Vserossiyskaya perepis naseleniya za 2010 god [All-Russian Census of Population for 2010]. Rosstat [Russian State Statistics Service]. URL: http://www.gks.ru/free_doc/new_site/perepis2010/ croc/perepis_itogi1612.htm (accessed October 10, 2016). 
4. V Chechne voyuyut inostrannye naemniki i turetskie spetssluzhby (pisma boevikov) [Foreign Hirelings and Turkish Special Services Militate in Chechnya (Letters of Hits)]. CentrAziya.ru. URL: http:// www.centrasia.ru/newsA.php?st $=1099730700$ (accessed September 27, 2016).

5. Genprokuratura otchitalas o blokirovke 450 saytov dlya sbora pomoshchi IGIL [A General Prosecution's Report about Blocking 450 Websites for Collection of Help for ISIS]. Slon.ru. URL: https:// slon.ru/posts/59437 (accessed September 30, 2016).

6. Dzhamaat Jarmuk. Vesti.ru. URL: http:// www.vesti.ru/doc.html?id=117504 (accessed September 30, 2016).

7. Dzutsev Kh.V., Pershits A.I. Vakhkhabity na Severnom Kavkaze - religiya, politika, sotsialnaya praktika [Wahhabity in the North Caucasus - Religion, Polical Issues, Social Practice]. Vestnik Rossiyskoy Akademii nauk, 1998, vol. 68, no. 12, pp. 1113-1116.

8. Dobaev I. Musulmanskoe obrazovanie v Rossii: sostoyanie, problemy i perspektivy na Severnom Kavkaze [Muslim Education in Russia: Condition, Problems and Prospects in the North Caucasus]. Perspektivy.info. URL: http:// www.perspektivy.info/book/musulmanskoje obrazovanije_v_rossii_sostojanije_problemy_ $\overline{\mathrm{i}}$ perspektivy_na_severnom_kavkaze_2008-06-04.htm (accessed September 30, 2016).

9. Zakon Karachaevo-Cherkesskoy Respubliki ot 4.05.2000 № 6-RZ «O protivodeystvii politicheskomu i religioznomu ekstremizmu na territorii KarachaevoCherkesskoy respubliki» [The Law no. 6-RZ of the Karachaevo-Cherkess Republic of May 5, 2000 “On Counteraction to Political and Religious Extremism on the Territoty of Karachaevo-Cherkess Republic"]. Elektronnyy fond pravovoy i normativno-tekhnicheskoy dokumentatsii [E-Fund of Legal and Regulatory Technical Documents]. URL: http://docs.cntd.ru/document/ 459904482 (accessed October 10, 2016).

10. Zakon Respubliki Dagestan ot 22.09.1999 № 15 «O zaprete vakhkhabitskoy i inoy ekstremistskoy deyatelnosti na territorii respubliki Dagestan» [The Law no. 15 of the Republic of Dagestan of September 22, 1999 "On the Ban of the Wahhabism and Extremism in the Republic of Dagestan]. Elektronnyy fond pravovoy i normativno-tekhnicheskoy dokumentatsii [E-Fund of Legal and Regulatory Technical Documents]. URL: http://base.garant.ru/26502658/ (accessed October 10, 2016).

11. Zakon Respubliki Ingushetiya ot 23.08.1996 № 13-RZ «O svobode veroispovedaniy i religioznykh organizatsiyakh» [The Law no. 13-RZ of the Republic of Ingushetia of August 23, 1996 "On the Freedom of Creed and Religious Confession"]. Elektronnyy fond pravovoy i normativno-tekhnicheskoy dokumentatsii [E-Fund of Legal and Regulatory Technical Documents].
URL: http://docs.cntd.ru/document/459800341 (accessed October 10, 2016).

12. Istoriya Khadzha Rossiyskogo [The History of Russian Pilgrimage to Mecca]. Islam.ru. URL: http:// www.islam.ru/content/history/30993 (accessed September 30, 2016).

13. Kalinina A. Basaev priberet k rukam kubyshku terroristov [Basaev will Control Terrorists]. Utro.ru. URL: http://www.utro.ru/articles/2005/03/09/ 415315.shtml (accessed September 30, 2016).

14. Karachaevo-Cherkesskiy dzhamaat [Karachaevo-Cherkessk Dzhamaat]. Agentura.ru. URL: http://studies.agentura.ru/to/russia/kchr/ (accessed September 30, 2016).

15. Knyazev V. V Rossii startuet islamskiy banking [Islamic Banking is Starting in Russia]. Ruekonomiks.ru. URL: http://rueconomics.ru/166195v-rossii-startuet-islamskii-banking (accessed September 30, 2016).

16. Malashenko A.V. Islamskoe vozrozhdenie v sovremennoy Rossii [Islamic Revival in Modern Russia]. Kavkaz-uzel.eu. URL: http://www.kavkazuzel.eu/articles/11411/ (accessed September 30, 2016).

17. Mezhdunarodnaya islamskaya organizatsiya «Spasenie» [International Islamic Organizationv "Spasenie"]. Politiktaym.ru. URL: http://www. politictime.ru/potis-404-1.html (accessed September 30, 2016).

18. Musulmanskiy fundamentalizm [Islamic Fundamentalism]. Islamskaya entsiklopediya [Islamic Encyclopedia]. URL: http://islamist.ru (accessed October 30, 2016).

19. Neulovimyy Ayub [Elusive Ajub]. Vremya novostey.ru. URL: http://www.vremya.ru/2003/1/13/ 30836.html (accessed September 30, 2016).

20. Nechitaylo D.A. Dzhihadisty s Severnogo Kavkaza v Sirii: mezhdu «Dzhabhat an-nusra» i «Islamskim gosudarstvom Iraka i Levanta»[Jihadists from the North Caucasus in Syria: between Jabhat alnusra and ISIS in Iraq and Levant]. Institut Blizhnego Vostoka [Institute of the Far East]. URL: http:// www.iimes.ru/?p=20237 (accessed September 27, 2016).

21. Proletenkova S.E. Islamskiy fundamentalizm: sushchnost, tendentsii, osobennosti [Islamic Fundamentalism: Essence, Trends, Special Features]. Of-law.ru. URL: http://of-law.ru/stati/islamskijfundamentalizm-sushchnost-tendentsii-osobennosti. html (accessed March 27, 2017).

22. 5000 rossiyan voyuyut $\mathrm{v}$ ryadakh IGIL: kommentarii ekspertov [5000 Russians Militate in ISIS Groups: Comments by Experts]. Rusvesna.su. URL: http://rusvesna.su/news/1434706866 (accessed September 30, 2016).

23. Religiovedenie [Religion Studies]. Entsiklopedicheskiy slovar [Encyclopedic Dictionary]. Moscow, Akademicheskiy proekt Publ., 2006. 1256 p. 
24. Sadikov M.I., Khanbabaev K.M. Religioznopoliticheskiy ekstremizm [Religious and Political Extremism]. Makhachkala, ITIMO Publ., 2009. 432 p.

25. Silantyev R.A. Vakhkhabitskiy proekt dlya Severnogo Kavkaza [Jahadist's Project for the North Caucasus]. Nezavisimaya gazeta.ru. URL: http:// www.ng.ru/ng_religii/2010-01-20/4_kavkaz.html (accessed September 27, 2016).

26. Skolko musulman zhivet $\mathrm{v}$ raznykh stranakh mira? [How Many Muslims Live in Different Countries of the World?] Muslim.ru. URL: www.islam-portal.ru (accessed September 27, 2016).

27. Torkunov A.V. Sovremennye mezhdunarodnye otnosheniya [Modern International Relations]. Moscow, ROSSPEN Publ., 1999. 584 p.

28. Troshev G.N. Moya voyna. Chechenskiy dnevnik okopnogo generala [My War. The Diary of a Chechen General]. Moscow, Vagrius Publ., 2001. 211 p.

29. Ukaz Prezidenta RF ot 15.02.2006 № 116 «O merakh po protivodeystviyu terrorizmu»: (s izm. $i$ dop.) [Enactment of the Russian President of February 15, 2006 no. 116 "On the Measures on Terrorism Prevention" (with amend. and add.)]. Access from Reference Legal System KonsultantPlyus.

30. Federalnyy zakon ot 25.07.2002 № 114-FZ «O protivodeystvii ekstremistskoy deyatelnosti»: (s izm. i dop.) [Federal Law of July 25, 2002 no. 114-FZ "On Counteraction to Extremist Activity" (with amend. and add.)]. Access from Reference Legal System KonsultantPlyus.

31. Federalnyy zakon ot 06.03.2006 № 35-FZ «O protivodeystvii terrorizmu» [The Federal Law of March 6, 2006 no. 35-FL "On Counteraction to Terrorism"]. Access from Reference Legal System KonsultantPlyus.

32. Federalnyy zakon ot 06.07.2016 № 375-FZ «O vnesenii izmeneniy $v$ Ugolovnyy kodeks Rossiyskoy Federatsii i Ugolovno-protsessualnyy kodeks Rossiyskoy Federatsii v chasti ustanovleniya dopolnitelnykh mer protivodeystviya terrorizmu $i$ obespecheniya obshchestvennoy bezopasnosti» [Federal Law of July 6, 2016 no. 375-FL "On Amending in the Criminal Code of the Russian Federation and the Criminal Procedure Code of the Russian Federation in Part of Establishment of Additional Measures of Counteraction to Terrorism]. Access from Reference Legal System KonsultantPlyus.

33. Chechenskaya Respublika Ichkeriya [Chechen Republic of Ichkeria]. Kavkazskiy uzel. URL: http://www.kavkaz-uzel.eu/articles/146418/\#note_1.

34. Chislo religioznykh organizatsiy, zaregistrirovannykh v Rossiyskoy Federatsii na 1 yanvarya 2005 goda [Number of Religious Organizations Registered in the Russian Federation as of January 1, 2005]. Federalnaya sluzhba gosudarstvennoy statistiki [Federal Service of State Statistics]. URL: http://www.gks.ru/bgd/regl/brus05/ IssWWW.exe/Stg/02-07.htm (accessed October 10, 2016).

35. Chislo religioznykh organizatsiy, zaregistrirovannykh v Rossiyskoy Federatsii na 1 yanvarya 2011 goda [Number of Religious Organizations Registered in the Russian Federation as of January 1, 2011]. Federalnaya sluzhba gosudarstvennoy statistiki [Federal Service of State Statistics]. URL: http:// www.gks.ru/bgd/regl/b1113/IssWWW.exe/Stg/d1/0213.htm (accessed October 10, 2016).

36. Chislo religioznykh organizatsiy, zaregistrirovannykh v Rossiyskoy Federatsii na 1 yanvarya 2015 goda [Number of Religious Organizations Registered in the Russian Federation as of January 1, 2015]. Federalnaya sluzhba gosudarstvennoy statistiki [Federal Service of State Statistics]. URL: http://www.gks.ru/free doc/doc 2015/ rusfig/rus-15.pdf(accessed October 10, 2016).

37. The Provision on Joining the Sufi Tariqats. Available at: http://www.binbaz.org.sa/noor/1159 (in Arabic).

38. Appeal to Muslims to Help Chechnya. Available at: http://www.binbaz.org.sa/article/430. (in Arabic).

39. The Order of Jihad in Chechnya and the Duty of Muslims to Follow It. URL: https://saaid.net/ Warathah $/ \mathrm{hmood} / \mathrm{h} 48 . \mathrm{htm}$. (in Arabic).

40. Chechnya is a Bleeding Wound. URL: http:// islamstory.com/ar/. (in Arabic). 


\section{ПОЛИТИЧЕСКИЕ НАУКИ И РЕГИОНОВЕДЕНИЕ}

\section{Information About the Author}

Elena F. Parubochaya, Candidate of Sciences (History), Associate Professor, Department of International Relations, Political Science and Area Studies, Volgograd State University, Prosp. Universitetsky, 100, 400062 Volgograd, Russian Federation, parubochaya@volsu.ru, polit@volsu.ru, http://orcid.org/0000-0002-2115-6595

\section{Информация об авторе}

Елена Федоровна Парубочая, кандидат исторических наук, доцент кафедры международных отношений, политологии и регионоведения, Волгоградский государственный университет, просп. Университетский, 100, 400062 г. Волгоград, Российская Федерация, parubochaya@volsu.ru, polit@volsu.ru, http://orcid.org/0000-0002-2115-6595 